\title{
ART-GUMENTACIÓN EN UN DISCURSO TURÍSTICO VIRTUAL. MADRID EN LA PÁGINA WEB DE TURESPAÑA: SPAIN.INFO
}

\author{
Laurence Chapuis \\ Rocío Herrero Riquelme \\ Flávia Gomes-Franco e Silva \\ Universidad Rey Juan Carlos. Madrid
}

\section{RESUMEN}

Turespaña es un organismo creado con el propósito de acometer acciones en el exterior para la promoción de España como destino turístico, por lo que era fundamental que tuviera una persuasiva presencia en Internet.

Basándonos en el análisis argumentativo de Amossy, estudiamos la estrategia discursiva desarrollada en la página de Madrid del portal de Spain.info para convencer al visitante virtual de viajar a la capital. Así, en ese contexto digital, mostramos cómo el locutor construye su imagen (ethos) y la de su destinatario, y maneja las relaciones entre ambos para cumplir con sus objetivos.

Palabras clave: argumentación; discurso; página web; turismo.

Art-gumentation in virtual tourist speech. Madrid on the website of Turespaña: spain.info

\section{ABSTRACT}

Turespaña is a Spanish tourist organization which was created in order to undertake specific actions abroad for the promotion of Spain as a tourist destination. For this purpose, a persuasive presence on the internet has been and is an essential characteristic.

Recibido: 11 de agosto de 2014

Devuelto para su revisión: 23 de enero de 2015

Aceptado: 20 de marzo de 2015

Facultad de Ciencias Jurídicas y Sociales. Universidad Rey Juan Carlos. Paseo de Artilleros, s/n. 28032 MADRID (España).E-mail: rocio.herrero@urjc.es 
This article has been based on Amossy's argumentative analysis. The authors have studied the discursive strategy developed on the website Spain.info, specifically the city of Madrid. The site will offer virtual tourist travel to the capital city of Spain. Thus, in the context of new technologies, the authors show how the speaker constructs his own image (ethos), the receiver's image and it manages the communication between them to achieve the goals.

Keywords: argumentation; speech; website; tourism.

\section{INTRODUCCIÓN}

En este artículo, nos proponemos analizar la argumentación en el discurso de la página web de la ciudad de Madrid, publicada en español desde el portal de Spain.info, donde el Instituto de Turismo de España - Turespaña - difunde la imagen del país en Internet desde el año 2002 (Rodríguez Abella, 2012). Dicho organismo procede del antiguo Instituto Nacional de Promoción del Turismo (INPROTUR), que pasó a denominarse Turespaña en $1988^{1}$.

Sin duda alguna, esta labor de promoción es de suma importancia porque, a pesar de un contexto económico incierto, el turismo ha obtenido el record de crecer hasta los 1.087 millones de viajeros internacionales en el año 2013. Los datos demuestran que el sector turístico es uno de los motores económicos más importante del mundo. Según el informe emitido por la Organización Mundial del Turismo, Panorama del Turismo Internacional, los resultados se traducen en elocuentes porcentajes: el turismo produce el 9\% del PIB mundial, casi el 10\% del empleo y hasta el 6\% de las exportaciones mundiales (UNWTO, 2014).

Turespaña, organismo dependiente del Ministerio de Industria, Energía y Turismo de la Administración General del Estado, se creó con el propósito de acometer acciones en el exterior para promocionar a España como destino turístico. Los instrumentos de marketing utilizados por dicho organismo son variados: campañas publicitarias en diversos medios - prensa, revistas, radio, soportes online, etc. - , siendo algunas de ellas de considerable repercusión como: Smile, you are in Spain o I need Spain. Asimismo, su misión esencial atañe a una industria que tiene un peso considerable en la economía española, a «un soporte insustituible» (Cuadrado Roura y López Morales, 2011: 20), por lo que parecía fundamental que el organismo encargado de la promoción turística tuviera presencia en Internet.

Teniendo en cuenta el incremento del total de la población mundial con acceso a Internet - un 566,4\% del 2000 al 2012 (Internet World Stats, 2012) - y el alcance de la información publicada, podemos aseverar que la Red ha revolucionado el sector turístico. Según el propio Turespaña (2015), el 80\% de los visitantes del país son usuarios de Internet (Turespaña, 2015). La voluntad de preservar la posición de España en el rango

1 Real Decreto 124/1988, de 12 de febrero, por el que se reorganiza la Secretaría General del Turismo y el Instituto Nacional de Promoción del Turismo. 
de los primeros destinos implica el trazado de una buena estrategia numérica, es decir, de las tecnologías 2 .

El sitio web analizado forma parte de una política general de presentar los recursos turísticos de España en su totalidad. Nuestro objeto de estudio en este caso se concentra en la página dedicada a la capital, en el período de observación comprendido entre el 2012 y 2014, que engloba varias versiones del portal, pues el organismo estrena una nueva en junio de 2013. Si bien el portal www.spain.info ha sido objeto de análisis (Chierichetti, 2010; Rodríguez Abella, 2012), la originalidad del presente estudio consiste en centrar la investigación en la página dedicada a la ciudad de Madrid. En este artículo, pretendemos analizar la página web en el marco del análisis argumentativo (Amossy, 2006) con la idea de alcanzar conclusiones diferentes y complementarias a las de otras disciplinas. Así pues, combinaremos esas líneas metodológicas con un enfoque comunicativo. Por lo tanto, nuestro objetivo es examinar la estrategia discursiva de persuasión llevada a cabo por un locutor (Turespaña) para presentar y promocionar el destino «Madrid» ante un auditorio lo más amplio y heterogéneo posible (los visitantes potenciales).

Obviamente, el portal web es producto de varios autores. Este discurso es, como el discurso publicitario o periodístico, «el producto de una colaboración colectiva negociada $»^{3}$ (Maingueneau, 2009a: 44), que atribuimos a un único locutor. En el marco metodológico propuesto por Amossy (2006), se destaca el poder argumentativo del ethos ${ }^{4}$ que remite a la presencia del locutor en el discurso, a los rasgos que proyecta de sí mismo para actuar sobre el público. La situación de enunciación incluye a un locutor preocupado por mostrarse favorablemente a su auditorio. La representación del destinatario compone, en este sentido, otro elemento esencial de la estrategia discursiva (2006), por lo que se construye una figura del visitante de la página en adecuación con el fin perseguido: los visitantes virtuales de la página web deben de convertirse en visitantes físicos de la ciudad. Así, determinado el estudio que nos ocupa, produciremos cierto desenfoque: la imagen del destino no constituye el centro de este trabajo; lo que nos ocupa es la interacción entre un locutor y su destinatario en torno al espacio promocionado. Pretendemos, en una primera parte, captar el ethos del locutor cuyo desarrollo es manifiesto en el soporte. Desde un campo interdisciplinar, mostraremos su ahínco por proporcionar una imagen de líder turístico mundial a través de un medio de gran calidad. Así, tras el análisis de los aspectos más técnicos de la página, comprobaremos el nivel de dinamismo de la misma y cómo repercute en la imagen que proyecta Turespaña. En una segunda parte, veremos cómo la estrategia argumentativa se organiza en torno a la representación del destinatario y mostraremos el pragmatismo del locutor que, para involucrar a un auditorio muy heterogéneo, hace distinciones en función de la variedad temática

2 Turespaña decide las líneas estratégicas pero gran parte de la ejecución está a cargo de SEGITTUR, sociedad mercantil con capital público que constituye un ente instrumental para llevar a cabo las acciones de diseño web, el mantenimiento del sitio, la subida de contenidos, tratamiento de las imágenes, etc.

3 Esta traducción del francés al español, así como todas las siguientes, son de las autoras.

4 Término procedente de la retórica griega que Aristóteles, en la Retórica, pone en relación con el logos (discurso, razonamiento) y el pathos (uso de los sentimientos). Los tres modos forman parte de la actividad oral de persuasión llevada a cabo por el orador. Según el análisis del discurso, el ethos del locutor es palpable en todos los textos: la imagen del que toma la palabra, tanto oralmente como por escrito, es determinante para conseguir la adhesión de su auditorio. 
del turismo. Para tal propósito, tendremos en cuenta los elementos que determinan la producción del enunciado: el género, el contexto, el medio y las técnicas discursivas.

Nuestro objetivo esencial responde a esa problemática: ¿Cómo Turespaña liga su imagen a un soporte de calidad? ¿De qué manera, en ese contexto numérico, dicho organismo involucra al destinatario en su discurso? ¿Cómo la imagen que se proyecta del destinatario es concebida como estrategia de presentación del destino y cuáles son las relaciones mantenidas entre ambas instancias? Veremos que, en muchas ocasiones, las respuestas a estas preguntas están vinculadas a los recursos artísticos de la capital, auténticos argumentos de peso en el marco de su promoción turística.

Como la página alberga un contenido tremendamente extenso, hemos optado por centrar nuestro análisis en los fragmentos que sirven nuestros objetivos previos.

\section{IMAGEN DEL LOCUTOR A TRAVÉS DEL PORTAL: A LA ALTURA DE LOS AVANCES TECNOLÓGICOS}

\subsection{Consideraciones sobre el género discursivo}

El género permite reagrupar los discursos en función de propiedades lingüísticas comunes, como lo son la intención comunicativa, el medio de producción, la disposición del contenido, el estilo, etc. Una oración fúnebre, una sentencia judicial o un folleto de la seguridad social, por ejemplo, son géneros discursivos que pertenecen respectivamente al discurso religioso, jurídico y administrativo.

Para poder llevar a cabo este análisis argumentativo, es preciso situar nuestro discurso dentro del ámbito turístico en función de nuestros objetivos de análisis, pues el marco institucional y discursivo es determinante para la finalidad del enunciado, la distribución de los papeles o la gestión del intercambio. Según Amossy (2006), la argumentación depende del marco discursivo en el que se desenvuelve.

No hay discurso sin género: el relacionarlos permite la interpretación y el entendimiento del mensaje. El medio Internet ha impulsado el uso de nuevas herramientas que modifican el formato, el alcance, la interacción, etc. de los documentos en papel y ha propiciado la creación de nuevos géneros. En el sentido en el que lo desarrollaron Shefferd y Watters (1998), la página web constituye un cibergénero que surge con el nuevo medio, pero en el ámbito turístico, se ha mostrado que su estructura conserva muchos rasgos de los discursos turísticos tradicionales (folletos, información práctica, etc.). Calvi (2006), a su vez, prefiere considerarlo como una combinación de géneros, dominados por una intención de promoción y cuyo conjunto posee una identidad propia.

No sin tener en cuenta los estudios exhaustivos realizados sobre el género en ese ámbito, hemos acordado, dadas las características del análisis llevado a cabo, considerar la página web institucional de turismo como un cibergénero en sí que se inscribe en la tradición del «tipo discursivo» (Maingueneau, 2009b: 138) turístico. El hablar de género permite observar la existencia de características comunes, que pueden ser, para las páginas web institucionales, la disposición de los contenidos, la naturaleza de la información, la utilización de eslóganes, etc. (González García, 2012), que se van elaborando conforme al tipo discursivo en el que se encierran. 
El portal de Spain.info no constituye una excepción: explota los recursos del medio y se sitúa en la rutina discursiva del turismo. El locutor aprovecha, por tanto, la posibilidad de introducir vínculos, imágenes fijas (fotos y gráficos) o en movimiento (vídeos). El buscador interno permite al usuario moverse con facilidad en función de sus necesidades y de la resolución de sus dudas. La página web funciona como un guía, con la difusión actualizada de su contenido de eventos. Si bien consagra a la capital un apartado completo y especial, los vínculos de la parte superior la sitúan constantemente dentro de un conjunto geográfico («Ciudades y pueblos»). La página web permite con un solo clic acceder a dimensiones espaciales diferentes, pero todas interrelacionadas.

El discurso se hila en torno a los habituales campos semánticos de cultura, gastronomía, alojamiento, etc., con las isotopías del placer, la singularidad y la excelencia; hace uso de múltiples adjetivos de valor axiológico positivo, superlativos e hipérbolas. Sus descripciones, al igual que los demás discursos turísticos, se componen de muchos datos sensoriales con un alto poder de evocación y combinan texto e imágenes sugestivas.

\subsection{Elementos explícitos de la figura del locutor}

La presentación explícita se ve allanada por el género. El apartado «conócenos» nos informa concretamente sobre su naturaleza y función, poniendo de relieve el carácter institucional de la página, que le confiere autoridad. El organismo muestra un compromiso con su labor y evidencia seriedad. Sin embargo, el mero hecho de que sea un organismo estatal encargado de promocionar el país puede restarle credibilidad. A menudo, los internautas les conceden más valor a las manifestaciones de sus pares, ya que, al carecer de objetivo comercial, resultan sinceras, cercanas y más convincentes. Además, se establece un proceso de identificación entre el internauta con ganas de efectuar un desplazamiento y el viajero que, en blogs o foros, relata los elementos más relevantes de su experiencia. Por lo tanto, la imagen del locutor debe resultar digna de confianza. Su extensa página muestra un buen conocimiento de la España turística, se constituye como una referencia en la preparación del desplazamiento, al tiempo que se muestra abierto a los discursos ajenos de los viajeros experimentados, ofreciéndole ilustración y complementariedad.

La presencia en Internet potencia, sin duda, el alcance del mensaje que se quiera transmitir, logrando un público cada vez más amplio y diversificado. Pero, entre tantos portales, la visibilidad se convierte en una prioridad. En este sentido, el locutor cuida el posicionamiento de la página web en los buscadores, puesto que aparecer en las primeras páginas de resultados facilita el acceso a los destinos promocionados, al tiempo que revela su primacía en el sector.

Una vez dentro del portal, para llegar a la página de Madrid, foco de esta investigación, el destinatario puede optar por acudir a la sección «Dónde ir» del menú principal, que se encuentra distribuido horizontalmente encima de la foto sin perjudicar la visualización de la imagen en sí. Otra alternativa sería introducir en su navegador la dirección electrónica completa (http://www.spain.info/es/que-quieres/ciudades-pueblos/grandes-ciudades/madrid.html) en el caso de que el usuario la conociera. Es legítimo pensar que el internauta accede a esa página con una motivación previa. Normalmente, la ubica porque busca información sobre Madrid. Turespaña cuenta, por lo tanto, con un destinatario cuyo interés va ligado a unas preguntas concretas a las que tiene que responder. Asimismo, debe crear una imagen de Madrid 
lo suficientemente atractiva para que esa inclinación de los destinatarios hacia la ciudad no mengüe. En este contexto de democratización de los desplazamientos y de ardua competencia turística, el destino puede entrar en competición con otros. En efecto, algunos internautas tienen decidido el lugar de viaje cuando acceden al sitio web después de una mínima búsqueda, pero otros consultarán simplemente la página con la idea de formarse una idea sobre la ciudad. Por ello, un discurso de calidad puede influenciar positivamente al indeciso.

\section{Figura 1 \\ SECCIONES DEL MENÚ PRINCIPAL}

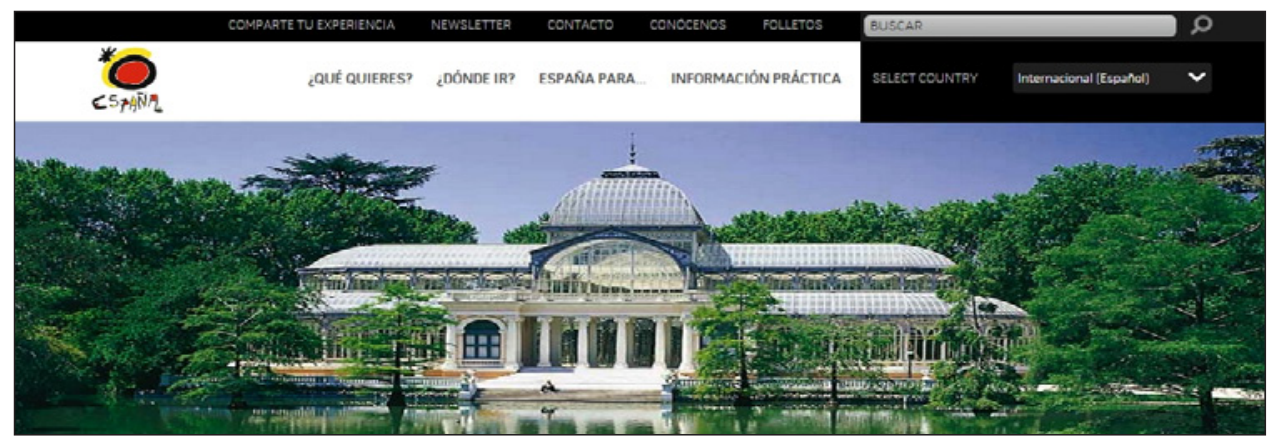

Fuente: Spain.info

\subsection{Propiedades técnicas y ethos}

El discurso de Turespaña se inscribe en un medio complejo: la web 2.0. Así, abrir una ventana en el universo virtual no significa simplemente disponer de un dominio y colgar los contenidos que, según el emisor, les puedan interesar a los usuarios. Internet ya no es una plataforma dedicada a la mera divulgación de información, como si de un escaparate se tratara. El locutor, y así lo atestigua la mejora de la página en el 2013, procura adaptarse a los elementos técnicos que condicionan el nuevo discurso digital, identificados como la multimedialidad, la hipertextualidad, la instantaneidad, la interactividad y la universalidad (Parra Valcarce y Álvarez Marcos, 2004). Cuando se diseñó el portal de Spain.info en el 2002, se trató de aprovechar todos los recursos disponibles en aquel momento para transformar la comunicación vertical en un arquetipo horizontal y dinámico de intercambio de conocimiento e información.

La combinación de los elementos técnicos citados anteriormente y el conocimiento de los patrones de visualización de la información en pantalla (Hassan Montero y Herrero Solana, 2007; Alt64 y AIMC, 2005) garantizan al diseñador un modelo digital intuitivo, accesible y, a la vez, dinámico. Para Alonso (2010: 45), el concepto de dinamismo está asociado al uso correcto de dichos elementos y, por tanto, «alude al grado de aprovechamiento que los nuevos medios hacen de las posibilidades que ofrece el soporte en línea». López García et al. (2005: 45) afirman que «precisar el nivel de dinamismo de un cibermedio es medir el 'grado de adecuación' de sus indicadores»: cuanto más dinámica sea una web, mayor será su grado de adecuación a la hipertex- 
tualidad, la multimedialidad, la interactividad y la frecuencia de actualización, factores clave a la hora de evaluar la estructura y el funcionamiento de una página en Internet.

Para ello, los autores proponen la realización de un test de dinamismo en el que se incorporan los cuatro ítems citados a una escala Likert, de 0 a 5, contemplando desde el menor hasta el mayor grado de adecuación. La suma de los resultados obtenidos a partir del análisis de los indicadores de dinamismo se podría ubicar en distintos niveles:

1. Nivel 1 (las webs menos dinámicas): entre 0 y 4 .

2. Nivel 2: entre 5 y 8 .

3. Nivel 3: entre 9 y 12.

4. Nivel 4: entre 13 y 16 .

5. Nivel 5 (las webs más dinámicas): entre 17 y 20.

Si nos regimos por los aspectos técnicos de un sitio web en relación a esos cinco elementos y sometemos la página elegida para esta investigación al test propuesto por López García et al. (2005), se observa un alto grado de adecuación.

La página inicial de Spain.info facilita la visualización de la información debido al uso correcto de los colores de fondo respecto al color que se emplea para el contenido. Por un lado, el fondo negro destaca la foto principal y, por otro, el fondo blanco y la fuente en tonos de gris ofrecen un contraste ideal para la lectura en pantalla. Al abrir la web de Madrid, el internauta encuentra un mismo modelo de navegación, que le permite acceder a la información que busca. La calidad de la página se debe sobre todo al diseño intuitivo y a la adecuada disposición de la información, que se ajusta a los patrones de lectura en pantalla por parte de los internautas. Una amplia foto centralizada y con óptima resolución encabeza la página junto al menú principal. No se trata, sin embargo, de una sola imagen. Mientras que el folleto turístico impreso, por ejemplo, no puede disponer de archivos de imagen y sonido que lo haga más atractivo, la multimedialidad da la posibilidad de añadir recursos audiovisuales a cualquier documento que se quiera divulgar a través de Internet. La reproducción del álbum virtual, compuesto por cuatro imágenes, no se activa automáticamente una vez abierta la página, sino que requiere la participación del destinatario que deberá pinchar en los botones no numéricos, localizados en la parte superior izquierda de la foto principal, para realizar el cambio de imagen.

Si bien la web exhibe visual y cromáticamente la capital española, al mismo tiempo, estimula la interacción usuario-máquina. Para ello, se aprovecha de la hipertextualidad, que deriva de la existencia de hipervínculos a otros sitios web (enlaces externos) o a los contenidos ofrecidos por la propia página en sus secciones y subsecciones (enlaces internos), desarrollando una macro y micronavegación, respectivamente. La presencia de hipervínculos enriquece el texto y ofrece al usuario la oportunidad de ampliar y contrastar la información dispuesta en el sitio web, rompiendo, de esta forma, con la lectura lineal. En el discurso sobre Madrid, esto se traduce por la gran cantidad de enlaces internos que dirigen al usuario hacia informaciones específicas sobre museos, oficinas de turismo, hoteles, restaurantes, etc. La información se agranda también al destino España, mediante los vínculos a las páginas del portal Spain.info que respetan el patrón de navegación, constituyendo así un conjunto discursivo homogéneo y coherente. 
Figura 2

\section{CABECERA DE LA PÁGINA}

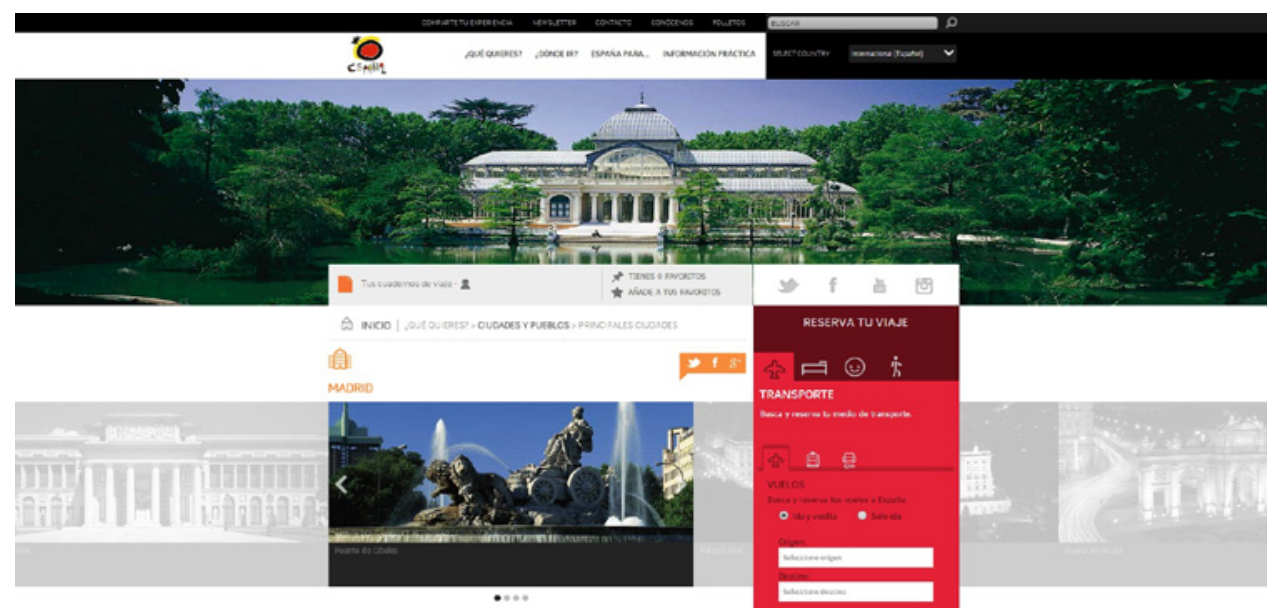

Fuente: Spain.info

Los avisos relativos a la actualidad se contemplan en la columna de la derecha, justo por debajo de la foto principal. Se facilita el calendario de eventos que se están llevando a cabo en Madrid, con las fechas de inicio y finalización para una mejor planificación del viaje. En el periodo de análisis, los acontecimientos dispuestos en dicha columna han sido actualizados mensualmente. La instantaneidad añade credibilidad a la página e incita a los internautas a seguir visitándola en ocasiones futuras para consultar los eventos que allí estén publicados.

\section{Figura 3}

\section{CALENDARIO DE EVENTOS E INFORMACIÓN ADICIONAL}
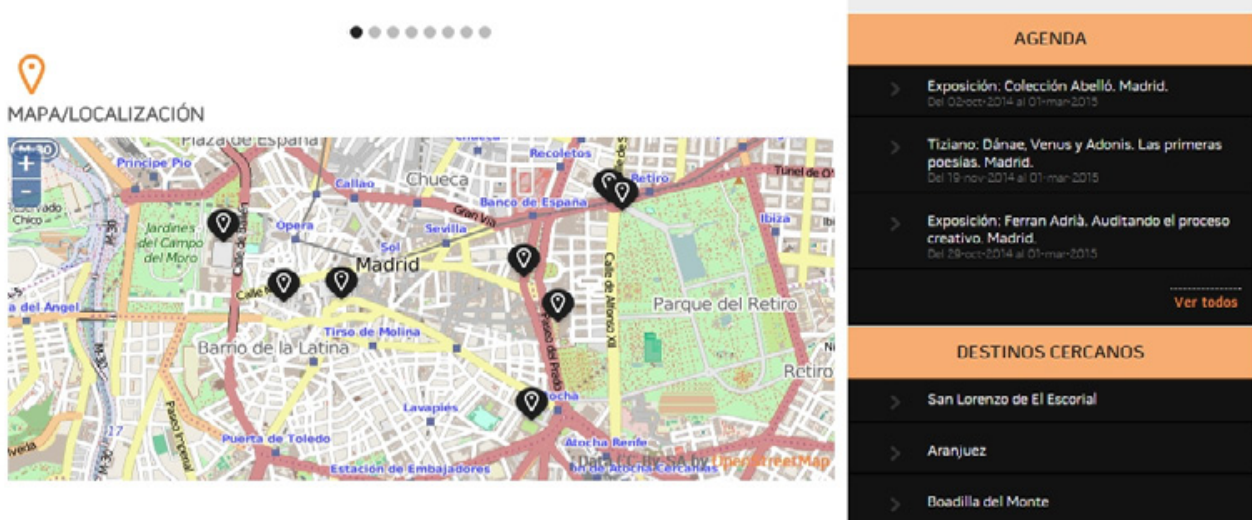

Fuente: Spain.info 
Otro elemento a tener en cuenta en ese cibergénero es la interactividad, principal aportación de la web 2.0 y responsable del cambio de postura del destinatario, quien abandona el puesto de mero lector-receptor para participar activamente en la Red. Dicho elemento se ve reflejado en la página a través de los enlaces que posibilitan la comunicación con el propio portal y con los demás usuarios. En el primer caso, el internauta cuenta con un hipervínculo dispuesto en el menú ubicado en la parte superior de la pantalla. Al pinchar en dicho enlace — «Contacto»—, se abre un formulario que deberá cumplimentar con sus datos personales para, enseguida, rellenar el campo denominado «Comentarios». Por otro lado, la interactividad usuario-usuario se sostiene a partir de la incorporación de los botones relativos a las redes sociales. Uno de ellos abre la página de Spain.info en Facebook, que se identifica como una organización gubernamental, mientras que el de Twitter da la bienvenida al usuario en inglés: «Welcome to Spain. Get ready for a trip to Spain! The official Twitter for tourism in Spain». El portal invita a seguirles igualmente en YouTube y en Instagram.

$\mathrm{Al}$ acceder a las páginas con información complementaria desde los enlaces internos, el usuario cuenta con la posibilidad de enviarle a un amigo el texto en cuestión o compartirlo en redes sociales. Cuando iniciamos el estudio en el año 2012, se echaba en falta un campo específico para la introducción de comentarios en la propia página, hecho que el organismo corrigió en el momento de la reelaboración de su página web. Se fomenta con ello la generación de una continua retroalimentación que facilita el sondeo sobre la opinión del público respecto al servicio que ofrece el sitio.

Teniendo en cuenta la distribución de la información textual e ilustrativa, así como los recursos utilizados por la página analizada, el grado de adecuación al que se refieren López García et al. (2005) es sin duda elevado, situando la página de Madrid, del portal Spain. info, en el nivel más alto de dinamismo. El locutor explota los recursos proporcionados por el medio y los combina con las características de los discursos tradicionales en papel, viéndose así propiciada la hibridez de los contenidos. Sobre este particular, Calvi (2009: 20) señala que «las páginas web institucionales [...] conjugan la fuerza promocional de los anuncios y de los folletos con una mayor riqueza informativa, propia de las guías, aprovechando también la flexibilidad y la interactividad del medio (...)». En su esmero por ser ejemplar en cuanto a aspectos formales, se presenta como el escaparate tecnológico de un país líder en turismo, abierto de par en par al visitante.

A continuación, veremos de qué manera el locutor perfila al destinatario y encauza las relaciones con el destinatario para incitarle a elegir Madrid como destino.

\section{INSCRIPCIÓN Y REPRESENTACIÓN DEL DESTINATARIO EN EL DIS- CURSO (TEXTO E IMÁGENES) DEL SITIO WEB}

\subsection{El destinatario previo}

Las funciones del locutor consisten en atraer, informar y proporcionar respaldo a un visitante potencial en la organización de su desplazamiento. Para acertar en el perfil de ese destinatario, Turespaña maneja estadísticas, encuestas y estudios que generan datos fiables sobre la conducta turística en España. Si bien el locutor no puede conocer per- 
sonalmente a los usuarios del portal, esa información le permite hacerse una idea previa y fidedigna de su auditorio. Este conocimiento de una situación real le da claves para orientar su estrategia de persuasión: en 2012, Madrid fue la sexta comunidad española en afluencia de turistas, con un total de 4.5 millones. El gasto por persona fue el más alto entre todas las comunidades (159 euros de gasto medio diario) así como la estancia media (7,3 noches). La capital sigue siendo el destino español más relevante para el turismo de negocios y estudios a pesar de haber sufrido un descenso en el número general de visitantes recibidos durante el año 2013 (-5,3\%) (FRONTUR, 2014). Una característica importante de Madrid es que no sufre el fenómeno de la estacionalidad. De hecho, su turismo se distribuye de manera proporcional en los cuatro trimestres del año. También es reseñable la diversificación de su mercado emisor, por lo que no existe una dependencia predominante con ningún país de origen (FRONTUR, 2013). En función de estos parámetros, Turespaña ha planeado la promoción de Madrid a escala planetaria, dirigiéndose a un auditorio procedente de distintas culturas y claramente «compuesto» (Amossy 2006: 58).

El discurso a un turismo heterogéneo conlleva sus dificultades que el organismo resuelve de distintas maneras. La primera consiste en tumbar la barrera lingüística. Para ello, el portal, en su totalidad, viene redactado en español y está enteramente traducido a tres idiomas más, inglés, alemán y francés por ser el Reino Unido, Alemania y Francia los principales mercados emisores de turistas en España ${ }^{5}$ (FRONTUR, 2014). El destinatario puede elegir la adaptación de la página a su nacionalidad y lengua a través de un menú-despliegue que hace distinciones; en particular, se diferencia para Canadá y Bélgica entre la comunidad francófona y los anglófonos y neerlandófonos. El locutor reconoce así el factor de identidad ligado a los pueblos dentro de cada nación. Elije mostrarse sensible y considerado: al hacer la diferenciación por idioma, se muestra respetuoso de la idiosincrasia de las distintas facciones de cada país.

En segundo lugar, la implicación de un auditorio plural pasa por la atención a un destinatario singular a través del uso de los deícticos de segunda persona del singular. Es mayoritario el tuteo en la versión española del portal — «Qué quieres», «Te proponemos»- aunque no exclusivo (también se encuentra algún «usted»). Este empleo da la idea de un solo interlocutor al tiempo que ataja la distancia entre las dos instancias. La apóstrofe amistosa que particulariza al destinatario es parte de la estrategia de argumentación del locutor. En efecto, el auditorio se ve designado por creencias, opiniones, valores que el discurso le atribuye explícita o implícitamente (Amossy, 2006). La individualización busca, en esa «nueva sociedad del ocio» (Olu, 2008), exhibir un servicio personalizado, conforme con los valores postmodernos de «experiencias personales, libertad individual, desestandarización» (Tanguay, 2004).

En tercer lugar, la dificultad de un auditorio diverso se solventa mediante la presentación, en la página de inicio, de un destino fragmentado: con el Madrid «Activo», «Gastronómico», «Para jóvenes», «Con niños», «De negocios», «De noche»y «De compras», la ciudad se ofrece al destinatario según una tematización bastante común de

5 En 2013, Reino Unido aportó a España un total de 14.327.277 turistas; Alemania, 9.854.760 y Francia, 9.525 .432 
los diferentes tipos de turismos. El locutor explota el estereotipo de las múltiples caras de la ciudad y el destinatario se mueve de hipervínculo en hipervínculo en función del interés que previamente tiene o que va desarrollando.

Figura 4

TEMATIZACIÓN DE TIPOS DE TURISMOS

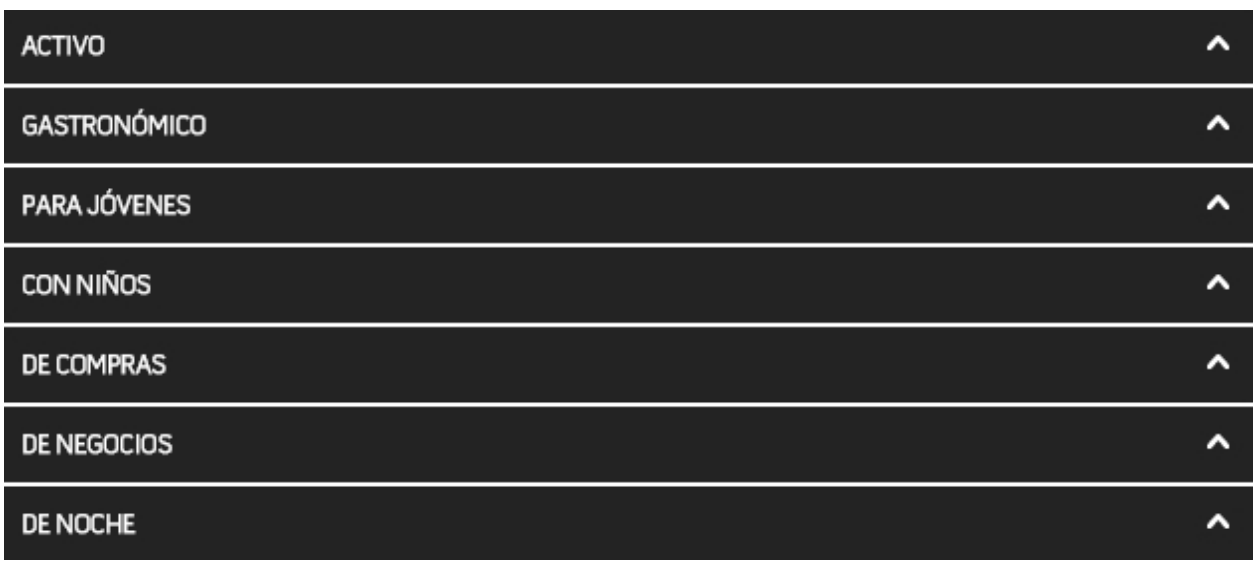

Fuente: Spain.info

Si bien el locutor exterioriza un trato diferenciado, la argumentación se inscribe dentro de una estrategia de incremento de la actividad turística. El locutor se dirige a un tipo de turismo en aumento: la particular atención al lucrativo turismo «de compras» (sintetizado en un apartado compuesto de cuatro subpartes), tradicionalmente vinculado al turismo urbano, ilustra ese propósito. Vemos en ese fragmento cómo el retrato del destinatario viene derivado de una observación minuciosa de las costumbres de consumo. Aquí, el locutor se dirige a un destinatario cuya motivación esencial para el viaje es el shopping. En lugar de hacer una diferenciación por perfil de comprador y arriesgarse a cometer simplificaciones en las que el destinatario no querría verse reflejado, se ha preferido hacer una tipología de las compras, segmentándolas en cuatro categorías.

La distribución diferenciada es aplicable a un tipo de comercios establecidos en territorios delimitados y atiende a criterios que, según el The Globe Shopper City Index (2012), motivan comportamientos adquisidores: el número de tiendas, marcas, la accesibilidad de las tiendas, los precios... Para todo ello, el locutor pone en marcha la retórica de la profusión y diversidad; la reiteración del verbo «encontrar» garantiza el hallazgo: «vas a encontrar una variedad enorme», «vas a encontrar toda clase...». Se ubica al destinatario, en función de la temática de compras, hacia unos recorridos dentro de espacios simbólicamente clausurados.

Vinculadas a lugares alternativos de la ciudad (Fuencarral, Hortaleza o Chueca), las «compras diferentes» se dirigen a un destinatario más joven. Encerradas «por el centro de Madrid y por la plaza mayor», las «compras tradicionales» refieren a los iconos identificables de la cultura española exportada, que se materializan en souvenirs como 


\section{Figura 5 \\ TURISMO DE COMPRAS}

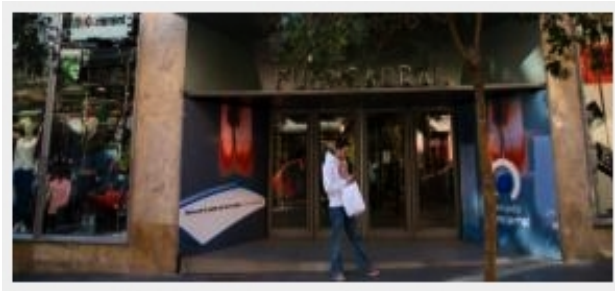

Un mundo de compras diferentes en Madrid

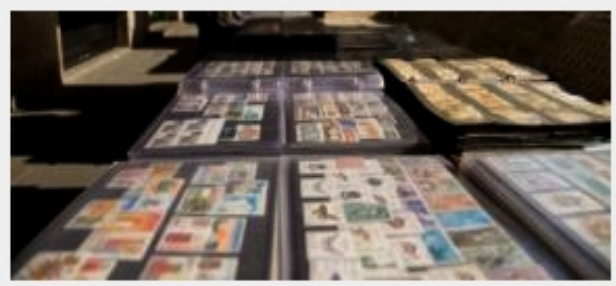

Madrid compras tradicionales

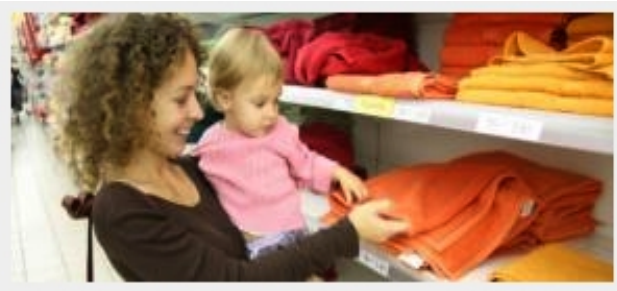

Madrid compras con tranquilidad

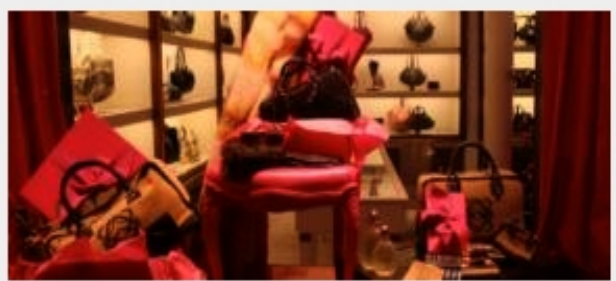

Madrid compras exclusivas

Fuente: Spain.info

los «abanicos, mantones de Manila, guitarras, capas, sombreros, bordados, cerámicas...». En ese caso, el locutor pone en escena a un turista que se lleva de regreso una evidencia de su paso por la región o ciudad visitada. Ubicadas de forma más abierta en «el casco urbano» y en los «centros comerciales» de «los alrededores», las «compras con tranquilidad» remiten a destinatarios con hijos. Atendiendo a la necesidad de los niños, se limita la improvisación con la codificación de las etapas de descanso en establecimientos, adaptados a ese público: «arrocerías, cafeterías, pizzerías, hamburgueserías, bocadillerías, vinoteras, etc...». En la cuarta categoría, designada por la etiqueta «compras exclusivas», se remite a un turismo de lujo incitado a deambular por el Barrio de Salamanca. Los correspondientes superlativos evocan el carácter distintivo de las marcas («tiendas más selectas y el trato más exquisito») que revertirán en el comprador, haciéndole sentirse único. La antonomasia sugestiva que designa a las tiendas de lujo como «la Milla de Oro» y la precisión de los «prestigiosos diseñadores de moda española como Amaya Arzuaga, Hannibal Laguna o Elena Benarroch» transmiten la ilusión de llevarse a casa un fragmento del país. El hecho de adquirir los bienes in situ, en el lugar del diseño y/o elaboración constituye un argumento de venta. La coincidencia entre el origen de la marca y el punto de compra carga el bien de valor añadido y genera la certeza de la consecución de un saber hacer artesano, moderno, específico de Madrid o de España.

La inferencia de las compras generalizadas («Madrid se presenta como una gran tentación a gentes de todas las edades») es sintomática de un turismo que antiguamente era minoritario (pocos podían ofrecerse el lujo de irse de rebajas por las grandes metrópolis) 
y que ha ido desarrollándose con Internet. El consecutivo surgimiento de las compañías low coast posibilitan, en efecto, la práctica de viajes cortos a precios irrisorios, con el principal atractivo de ir paseando de tienda en tienda, admirar escaparates, hallar productos raros y de calidad, comparar precios, etc. El estudio del espacio discursivo dedicado a este auditorio revela su importancia - el turismo de compras procedente, en muchas ocasiones de países emergentes, está en crecimiento-. Pero también desvela el afán por dignificar esa actitud, ya que el retrato consumista se ve amortiguado por la introducción de unos matices: el refinamiento (el destinatario tiene gusto, es conocedor de las grandes marcas símbolos de elegancia) y la autenticidad (el destinatario inquieto se esfuerza por conseguir el producto desplazándose hacia su lugar de origen). Ese ejemplo sirve para mostrar que el locutor no sólo esboza un retrato de su interlocutor a partir de datos económicos o sociológicos, sino que teja, en el discurso, un perfil de viajero en el que el destinatario va a quererse ver reflejado.

\subsection{La construcción de un destinatario «distinguido»}

El locutor retrata al destinatario en función de los datos objetivos, que le han sido suministrados con anterioridad por los organismos competentes, pero adapta su trazo a la estrategia discursiva, borra los rasgos inconvenientes, lo reelabora, lo perfecciona (Amossy, 2006). Así, el locutor encasilla a su público en enunciados genéricos definitorios que refieren a sus gustos, actividades o costumbres: «los amantes de los animales y curiosos de la naturaleza» y «aquellos más inquietos» («Madrid con niños»); «los más deportistas» $\mathrm{y}$ «aquellos que se decant[a]n por la cultura»... Las generalizaciones se fundan sobre una propiedad que agrupa siempre ventajosamente a los distintos destinatarios. En cada sección temática, se le da forma a un perfil: en «jóvenes», por ejemplo, se presupone un perfil de estudiante activo con un presupuesto relativamente bajo (se mencionan las iniciativas públicas «con un sinfín de actividades gratuitas») y ganas de salir y cultivarse. La adaptación al joven pasa por el uso de un registro más coloquial. Se acude a los anglicismos portadores de la cultura metropolitana («dj's», «afterhours»). Para él, la ciudad es erigida como el centro paradigmático del trasnoche, del ambiente nocturno festivo (se hace referencia a la «marcha», el «ocio nocturno»). Se trata, para la ocasión, de reanudar con el estereotipo de la ciudad festiva.

La construcción del destinatario está en consonancia con la imagen de la ciudad que se busca proyectar. En ese aspecto, y aunque el discurso sobre el destino se circunscriba a objetivos recursos culturales y naturales, notamos que la representación de Madrid no difiere mucho de la de otros espacios turísticos urbanos: sigue la tendencia de una argumentación basada en la mezcla de tradición y modernidad. Así, Madrid se presenta de forma dual, como activa capital del país y como histórica villa del reino; desempeña su función como centro de Estado sin perder las características propias de las vetustas poblaciones.

A través de la imagen dinámica de Madrid, se percibe una atención al turismo de negocios; el Madrid lúdico o recreativo está destinado al público de «jóvenes» y «niños». Pero, por encima de todo, Madrid se presenta cultural: palabras e imágenes se combinan en torno a una valoración clásica del patrimonio histórico y artístico de 
la ciudad. En efecto, el texto informativo de la página principal se despliega sobre los grandes recursos de la capital. De manera sintética y con alguna imprecisión ${ }^{6}$, se muestra una representación de patrimonio material (arquitectura, pintura, escultura) e inmaterial (costumbres, fiestas, tradiciones), conforme a lo expuesto a continuación:

- $1^{\circ}$ párrafo (el más importante): resalta el perfil cosmopolita de Madrid e, inmediatamente, del legado histórico, recurso constante en la página web. En este fragmento, se destacan de Madrid dos cualidades: la primera habla de la ciudad moderna, centro económico y financiero; la segunda trata sobre su importancia histórica, cultural y artística.

- $2^{\circ}$ párrafo: Casco histórico. Valoración de las infraestructuras y tecnologías. Exaltación de la personalidad madrileña (dinámica, abierta, alegre y acogedora).

- $3^{\circ}$ párrafo: Madrid de los Austrias, destacando solo la Plaza Mayor. No menciona otros monumentos y enclaves importantes del Madrid de los Austrias, Madrid de las letras, Plaza de la Villa, Palacio de Santa Cruz, Palacio de Uceda.

- $4^{\circ}$ párrafo: Palacio Real - en el texto se data al Palacio como una construcción del siglo XVII, pero se trata de una fecha errónea, puesto que comenzó a edificarse en el segundo tercio del siglo XVIII-, Plaza de Oriente, Teatro de la Ópera, Catedral de la Almudena. Se echa en falta el Monasterio de La Encarnación (casi en la misma plaza) o Las Descalzas Reales (entre Calle Mayor y Sol). De la puerta del Sol, destaca su perfil comercial sin nombrar ningún edificio o monumento. Menciona el paseo del arte, con sus museos, palacios y jardines, completados con otros monumentos: Banco de España, Palacio de Telecomunicaciones y las Fuentes de Cibeles y Neptuno. Sin embargo, ignora el Palacio de Linares y la Fuente de Apolo.

- $5^{\circ}$ párrafo: dedicado a los museos. Señala la presencia de más de 60 museos en la capital, destacando los tres situados en el Paseo del Prado: el Museo del Prado, el Museo Thyssen-Bornemisza y el Centro Nacional de Arte Reina Sofía. No hace alusión a otros enclaves culturales significativos próximos, como son CaixaForum, Fundación Mapfre, Museo Nacional de Artes Decorativas, Museo Naval y Museo Arqueológico Nacional.

- $6^{\circ}$ párrafo: trata de los parques e infraestructuras modernas.

- $7^{\circ}$ párrafo: pasión por la vida, carácter amistoso de su gente. Oferta cultural: exposiciones, conciertos y danza. Gastronomía con bares y tabernas. Oferta comercial y de compras tanto en puestos tradicionales como marcas internacionales.

- $8^{\circ}$ párrafo: vida nocturna, ambiente de bares, discos, tablaos, verbenas, fiestas populares y feria taurina de San Isidro.

De la misma manera que en las guías de viaje, se elabora un discurso sobre consideraciones genéricas relativas a la memoria y el valor histórico del lugar, marcado por las huellas de «didacticidad» (Moirand, 2004: 152) propias del género. La selección de las

6 El entorno numérico que acarrea cierto relajo en el rigor y la calidad del discurso ha permitido que se colaran ciertas imprecisiones, incluso errores históricos; la mayoría de ellos se ha ido corrigiendo con el tiempo. 


\section{Figura 6 \\ FUENTE DE CIBELES, PALACIO REAL, PUERTA DE ALCALÁ Y MUSEO DEL PRADO}
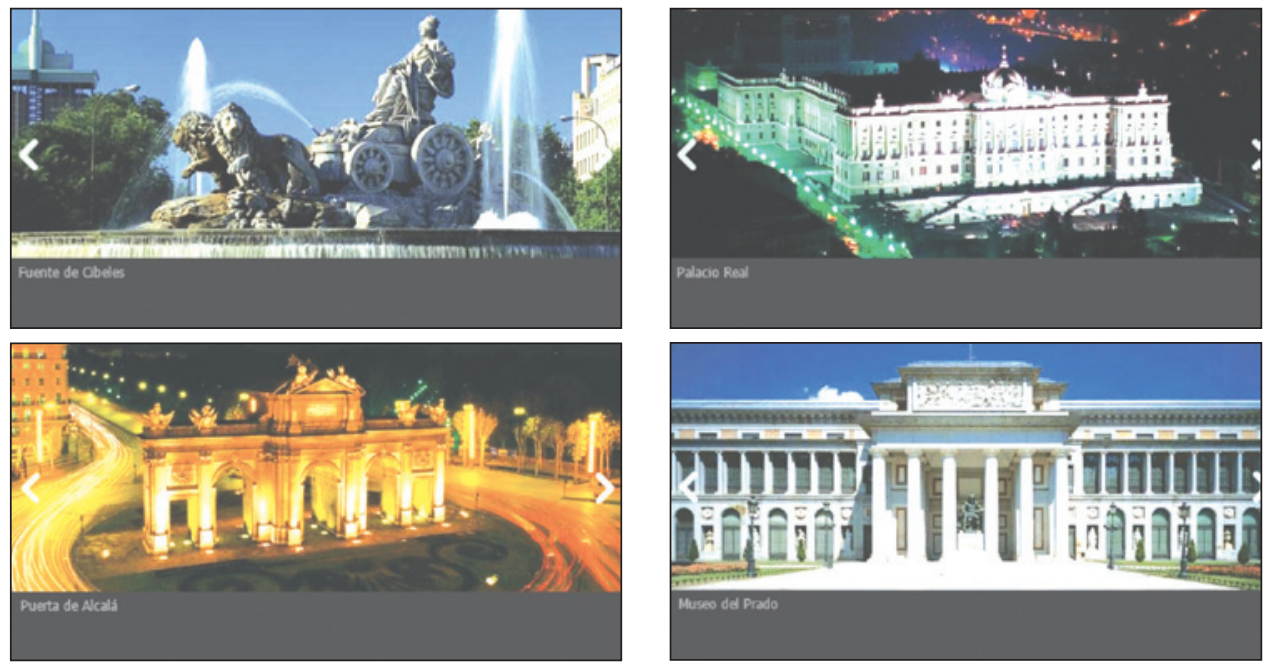

Fuente: Spain.info

cuatro instantáneas centrales se adecúa a la voluntad de una representación históricamente rica e inspiradora de la ciudad. Intervienen algunas arquitecturas pertenecientes al delimitado «Madrid de los Borbones $»^{7}$ y distribuidas de la siguiente manera:

- $\mathrm{N}^{\circ}$ 1: fuente de la diosa Cibeles (finales del siglo XVIII, reinado de Carlos III) como imagen principal de la página.

- No 2: vista nocturna del Palacio Real desde los jardines de Sabatini (siglo XVIII, inicio de la dinastía Borbónica).

- $\mathrm{N}^{\mathrm{o}}$ 3: vista nocturna de la Puerta de Alcalá (siglo XVIII, reinado de Carlos III).

- $\mathrm{N}^{\circ}$ 4: Puerta principal del Museo del Prado con escultura de Velázquez (siglos XVIII-XIX, reinados de Carlos III y Fernando VII).

La nueva versión del portal añade, no obstante, un matiz a esa dimensión. Las imágenes citadas se complementan con una panorámica, menos estandarizada, que encabeza la página y parece destinada a renovar, a la par que a reforzar, la imagen del destino. El locutor combina historia, arte y naturaleza con una poética imagen del Palacio de Cristal que se abre a los árboles del Retiro. La arquitectura sobresale luminosa entre un bosque frondoso. La ausencia total de movimiento transmite paz y sosiego, porque, al despojar el espacio de representación humana, se anula el transcurrir diario de los

$7 \quad$ La llegada de los Borbones al trono español supuso para Madrid una mejora sustancial debido a las reformas arquitectónicas y urbanísticas llevadas a cabo, principalmente, por los primeros monarcas de la nueva dinastía española: Felipe V, Fernando VI y sobre todo por el «mejor alcalde de Madrid», Carlos III. 
usuarios del parque. En esa porción representada, el entorno vegetal camufla lo cotidiano. El conjunto consigue mayor profundidad gracias al estanque en el que se refleja la naturaleza organizada: la cromática dominante, el verde, realza la armonía de ese lugar íntimo. Debemos destacar también que de estas imágenes principales, seleccionadas por el portal turístico, el Palacio de Cristal es la única que se ubica cronológicamente a finales del siglo XIX. Concretamente, corresponde a una corriente arquitectónica basada en la utilización de nuevas técnicas y materiales como fueron el hierro y el cristal y que se extendió por toda Europa. Por lo tanto, se trata de un ejemplo monumental que se diferencia histórica y estéticamente de las anteriores obras nombradas. De manera sinecdótica, el locutor estira, extiende ese lugar de vivir y soñar a la ciudad; caracteriza a un Madrid «paraíso» y suscita el interés por ir a conocer, o a reconocer, el lugar idealmente configurado en la fotografía.

Figura 7

\section{PALACIO DE CRISTAL. PARQUE DEL RETIRO}

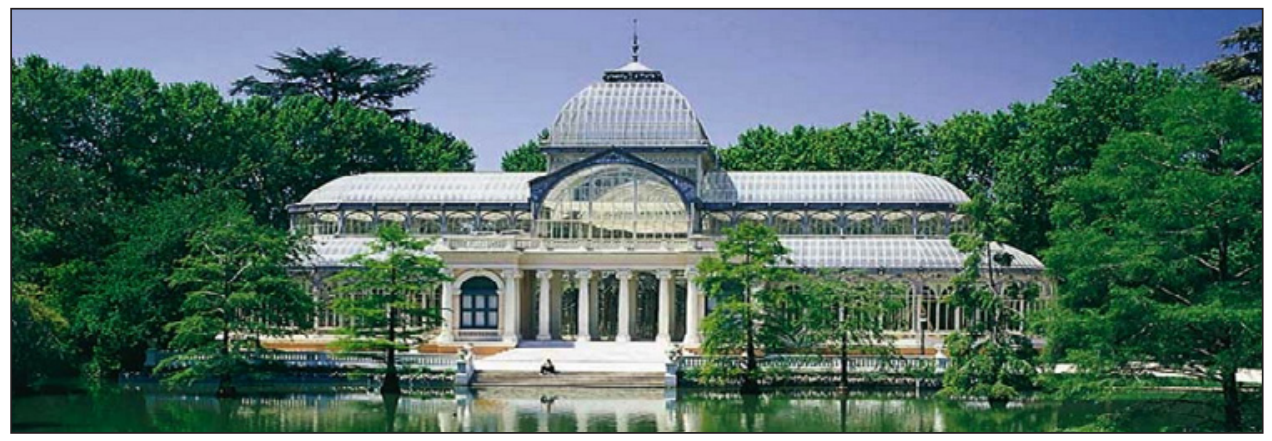

Fuente: Spain.info

La imagen, «consubstancial al turismo» despierta el deseo de movilidad (Coëffé y Violier, 2008: 19). Por eso, el locutor exhibe un programa iconográfico que crea una identidad madrileña basada en un sugestivo sustrato histórico, artístico y cultural. Destaca, mediante video e imágenes, la obra de arte y su santuario: el museo. Mediante la preponderancia discursiva, se realza la importancia de la pinacoteca del Prado, sobre todo, pero también de otras tres instituciones artísticas: el Centro Nacional de Arte Reina Sofía, el Museo Thyssen-Bornemisza y, en menor medida, el Museo Sorolla. La argumentación basada en la temática cultural dignifica a los participantes de la interacción, tanto el locutor como el destinatario. En ese proceso de relación de turismo y arte, el discurso pone en escena a un amante de la pintura. No obstante, no se dirige exclusivamente a los apasionados. Reconoce en ese interés turístico distintos grados de entrega a los que responde con varias maneras de abordar el patrimonio.

La intensidad en la práctica no aparece contradictoria con momentos de encuentro acotados. De hecho la oferta de la ciudad pretende ajustarse a una pluralidad de temporalidades y aunque la motivación primera no sea cultural, al visitante se le presta el deseo de encontrar en el viaje una forma de seguir aprendiendo. Para acceder a ella, se 


\section{Figura 8 \\ MUSEO DEL PRADO Y MUSEO NACIONAL CENTRO DE ARTE REINA SOFÍA}
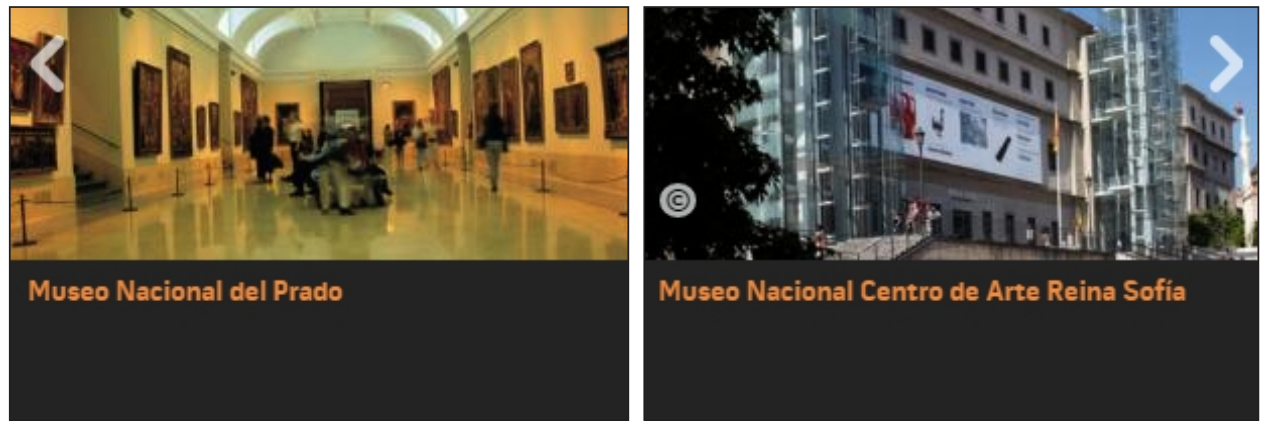

Fuente: Spain.info

utiliza la retórica de lo esencial y etiqueta como «imprescindibles» el arte (museo del Prado, Thyssen...) y la arquitectura (la Puerta de Alcalá, el Palacio Real, etc.). De esta manera, se atiende a un destinatario de breve estancia y se le facilita el encuentro con el patrimonio en un apartado específico («Un día cultural en Madrid»), proporcionándole la posibilidad de una «concentrada» relación sensorial con la ciudad, con esta promesa: «un día en Madrid da para mucho».

Al visitante, se le propone recorridos exprés en museos, circuitos cortos en la ciudad y herramientas adaptadas a la visita: planos, ayuda cualificada y productos turísticos («Es muy recomendable el uso de audioguías», refiriéndose a «Un día cultural»). Se le da una serie de consignas («Una buena hora para iniciar la visita sería las 9:30... optamos por una visita de dos horas y nos reservamos algo de tiempo para las salas que más nos interesan»). Se le proporciona indicaciones prácticas («el museo cierra los lunes») y planifica las paradas y los lugares de observación. Con tono descriptivo y prescriptivo, el discurso marca las reglas de un comportamiento diligente y astuto: «Las ciudades se conocen por sus calles, por lo que es una buena idea aprovechar la cercanía de la Puerta del Sol para dar un paseo».

El locutor, en su función programática, también explota la importancia del componente alimenticio en el descubrimiento del lugar. Selecciona en la materia local los productos evocadores de una tradición gastronómica. La enumeración de los alimentos permite la identificación a la cultura madrileña, se responde explícitamente a la búsqueda turística de tipicidad y autenticidad («En Madrid es típico...»). En todos los idiomas de redacción del portal, el locutor mantiene una profusión de términos culturales - palabras que «no tienen referente en las otras culturas» (Calvi y Mapelli, 2010: 46) - que dotan el discurso de cierto exotismo culinario; al destinatario se le recomienda «reponer fuerzas a la española», probar un «pincho», unas «tapas de tortilla», «patatas bravas», «boquerones», una «caña» o un «chato de vino». A través de la recomendación de estas prácticas, se crea la ilusión de una participación a la cultura local y de una relación a la alteridad. 


\subsection{Relaciones entre el locutor y el destinatario}

Ya dijimos que el discurso de Turespaña pertenecía a un cibergénero, de modo que son dos vertientes las que tenemos presentes. Sabemos, por una parte, que el género discursivo moldea la naturaleza de los papeles discursivos y que, por otra, el entorno numérico ha permitido la creación de nuevas formas de comunicación mediada por ordenador. En ese cibergénero, el locutor establece fácilmente relaciones que favorecen la incorporación del destinatario. El dispositivo numérico propicia considerablemente el establecimiento de un vinculo entre locutor y destinatario: la web 2.0 ha transformado el anterior escaparate divulgativo en una herramienta para la construcción colaborativa de la información que se comparte.

En este contexto, el locutor sabe que el destinatario ya no accede pasivamente a un contenido, sino que busca formas de interactuar con aquel que lo ha publicado y con la propia página web, sea para solicitar información complementaria, aportar sugerencias, corregir errores textuales o compartir la publicación con su red de amigos. Digamos que la interacción escrita, en ocasiones simbólica, ya no es producto de un locutor que se dirige a un auditorio y anticipa sus reacciones, sino que el medio favorece la posibilidad de un verdadero intercambio, aunque diferido. Las redes sociales, muy propias de este género, son reveladoras de esa tendencia a la elaboración participativa de contenidos, a la co-construcción del significado; también lo son las encuestas formuladas al internauta con la intención de producir un servicio cada vez mejor. El locutor se muestra receptivo, por lo que la elaboración de un nuevo portal en 2013 responde a la consciencia de una necesaria adaptación a la demanda de los internautas (Turespaña explica en su página web que la nueva versión propone una navegación mejorada). Al ser beneficiarios directos del potencial comunicativo de la Red, los internautas motivan la investigación de nuevas técnicas de desarrollo de páginas web centradas en la creación y consumo de contenidos.

El locutor se relaciona con un destinatario emancipado que se involucra en la organización de sus vacaciones y lo vincula, a su vez, a un espacio ajeno. Desde que existe el llamado «e-turismo», el viajero ya no acude tanto a los intermediarios que habría conocido en el «mundo físico» para la preparación de su desplazamiento. Turespaña funciona entonces como un mediador entre un destinatario procedente de un determinado territorio y un destino singular y diferente. Viajar implica romper con lo cotidiano, moverse por espacios nuevos que uno no domina. El discurso proporciona claves al futuro visitante para entender y apropiarse de la ciudad. Pero la relación de ayuda tiene vocación a ser duradera, extensible al mundo físico; las palabras buscan materializarse más allá del formato virtual. Y es que el locutor en la distancia tiene un homólogo en la cercanía, de modo que la comunicación en tiempo diferido se pueda mantener, más adelante, en tiempo real. En efecto, el portal es institucional y como tal, remite a la red de los actores locales públicos del turismo («Centro de Turismo de Madrid», «Oficina de Turismo de la Comunidad de Madrid», «Punto de Información Turística Paseo del Arte», etc.), cuyo discurso participa de la difusión de la notoriedad turística de los monumentos.

Por tanto, el locutor encuentra una prolongación en la comunidad local de expertos; se avisa al visitante que podrá seguir informándose una vez in situ: «Frente a la fuente de Neptuno, encontraremos un punto de información turística. En él, podremos recoger un 
plano del casco antiguo de Madrid». Los enlaces a un locutor físico que toma el relevo permitirán fortalecer la relación del destinatario con la ciudad. El uso de la primera persona del plural que incluye a las dos instancias del discurso es bastante revelador de este pacto simbólico que compromete al locutor-mediador hacia su destinatario.

No obstante, las estrategias de escenificación del locutor varían en función del objetivo perseguido. Hemos visto que se muestra presente para brindar apoyo. Ahora veremos que también camufla su presencia. En esta faceta, destino-destinatario se vinculan sin tercero aparente. El discurso se focaliza sobre el viajero y lo sitúa en medio del espacio, en total interacción con el entorno: la ciudad se asoma en el discurso y se entrega como un regalo («Madrid para ti»). En una programada cronología, se le propone una sucesión de acciones a realizar, en unos trayectos balizados con referencias espacio-temporales profusas («tras la comida... el Palacio Real de Madrid y sus imponentes alrededores. Sobre las 16:00... primera parada a través de la calle Mayor», en «Día cultural en Madrid»).

La variación en la perspectiva es un procedimiento discursivo recurrente en las guías de viaje: el espacio se transfiere al visitante potencial con la idea de que éste «experimente su propia subjetividad» (Vergopoulos y Flon, 2012). En tono exhortativo, el uso de la segunda persona con el futuro se relaciona con las actividades en el destino urbano y le permite anticipar emociones y placer: «disfrutarás plenamente en los grandes restaurantes de Madrid... hallarás a reputados chefs... podrás tomar el brunch en algunos hoteles de lujo» (en «Madrid grandes restaurantes»). Se marcan sensorialmente los rituales del descubrimiento a través del uso de los verbos de percepción, así como de los substantivos y adjetivos que narran formas, colores, volúmenes, música y sabores, etc. A veces de forma imperativa, se fomenta una actitud receptiva a determinados estímulos vinculados a particularidades locales: «sienta el ambiente popular y animado de sus tabernas y mesones» (en «De ruta gastronómica por Madrid»). En otras ocasiones, se le ofrece un mundo diverso de posibles sensoriales: «la noche de Madrid la puedes vivir con tranquilidad disfrutando de un buen cóctel en locales de diseño (...) mientras suena la música de fondo» (en «Noche tranquila en Madrid»); o bien «en el museo del Prado de Madrid podrá contemplar las obras de los grandes maestros de la pintura (...). Se emocionará, disfrutará...» (en «El museo del Prado, una visita imprescindible»). El espacio perceptivo se construye visual, gustativa y sonoramente. El locutor explota el campo léxico del placer (marcado por la repetición del verbo «disfrutar») de manera que, cuando el viaje se concrete físicamente, el destinatario salga en búsqueda de las imágenes que le han seducido.

El locutor relaciona su interlocutor con la ciudad, pero también lo vincula a una comunidad de viajeros cuyos testimonios se erigen bajo la cubierta de la institución que los avala. En la pestaña «comparte tu experiencia», se abre una ventana nueva que dirige a un espacio singular y subjetivo de expresión, el lugar de los «Spain addicts», con esa invitación «share.spain.info». Recoge, con frases y fotos sugestivas, el sentimiento de los viajeros no sólo por Madrid, sino por España entera. Aparece un cartel rectangular, blanco y rojo, en el que el destinatario pincha para «entrar». Se exhibe una frase mayúscula: «Sólo tú sabes porqué a veces escuchas esa voz que te dice necesito España». La tipografía enfática subraya dos tipos de entradas: el ingreso a un nuevo espacio y la intrusión de Turespaña que se adentra en la mente del internauta. Sabe lo que piensa y lo transcribe: la mención a la «VoZ», así como el paso de la segunda a la primera persona del singular 
(«escuchas... necesito»), estructura el monólogo interior del internauta. La ausencia de las marcas tipográficas características del discurso directo (se prescinde de las comillas) marca el sentimiento efusivo y el ímpetu del que ha viajado por España. Las personas empleadas y la referencia a algo tan personal como la voz interior dotan el espacio de privacidad. Al tiempo, ese segmento remite a la campaña internacional en vigor, I need Spain (para mayor fluidez, el eslogan se incorpora en su forma traducida).

\section{Figura 9 \\ ESPACIO «SPAIN ADDICTS»}

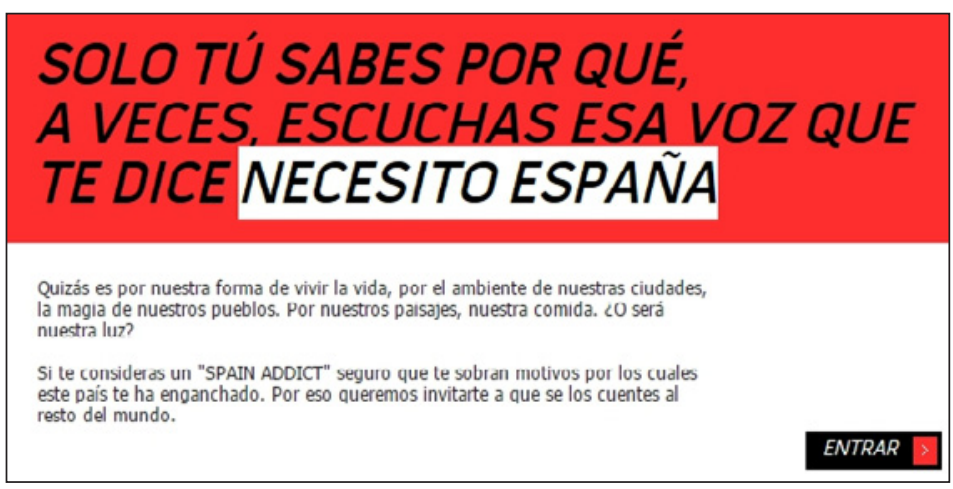

Fuente: Spain.info

Los spots y las piezas gráficas ${ }^{8}$ aportan la visión sensible del turista que, gracias al destino, accede a la parte más íntima de su ser. El destino lo revela a sí mismo, al modo de un espejo capaz de reflejar los lugares más recónditos de la persona. Este proporciona, en efecto, una experiencia sensorial capaz de influir positivamente en el desarrollo personal de cada uno y genera, a su vez, el imperativo de una vuelta. En el portal, Turespaña alarga el alcance de los mensajes de la campaña y elabora un lugar de respuestas para los auténticos viajeros: los protagonistas ya no son los modelos o actores de la campaña que interpretan un papel, sino autores profanos que, al firmar su producción discursiva, se inscriben fiablemente en el texto. Turespaña se dirige aquí explícitamente al viajero que ha estado en España e implícitamente al que no lo conoce aún: «Si te consideras un SPAIN ADDICT seguro que te sobran motivos por los cuales este país te ha enganchado. Por eso queremos invitarte a que se lo cuentes al resto del mundo». Esa apóstrofe al destinatario, con un «tú» de connivencia, da la garantía de que quien ahí entra está a la altura de la confidencia solicitada.

Una vez abierta la puerta, el destinatario está expuesto a representaciones subjetivas del territorio. A través de un mensaje multimodal, los locutores-viajeros hacen entrega de un momento relevante de su estancia de la península. En este lugar previsto para ellos, cuel-

8 La campaña se realiza en distintos formatos y soportes: spots de televisión (con visibilidad en internet), revistas, periódicos y vallas publicitarias. Busca enseñar la diversidad del destino así como la de sus productos, consolidar su posicionamiento en Europa y reforzarlo en los mercados emergentes. 
gan un vídeo o una foto acompañados por una breve leyenda; el conjunto ilustra momentos de particular intensidad, fuera del tiempo cotidiano: «Siete de la mañana, un día de verano y una mística humedad en el aire que daba a este pequeño bosque de eucalipto cerca de Santiago de Compostela un aura especial». El locutor-viajero se enseña observador y poroso: penetra el lugar y se deja penetrar por él, se expone y se abre a la sensibilidad.

Los entornos, mil veces representados, se perciben, no obstante, poco saturados, ya que aparecen en toda su dimensión estética (la instantánea forma un conjunto original con el mensaje). Cualquier usuario tiene la posibilidad de reaccionar ante las publicaciones, se le invita a contribuir al intercambio («deja aquí tu comentario»), a implicarse, a identificarse con los viajeros y a proyectarse, sobreentendiendo que la vivencia original de uno, sin poder ser idéntica (porque es irrepetible), puede ser colectiva: un estado abierto garantiza a todos una experiencia.

\section{CONCLUSIONES}

El acontecimiento de los vuelos baratos ha permitido ampliar la actividad turística hacia destinos interiores que requieren una atractiva presentación. Así, dentro del ámbito promocional, el portal Spain.info muestra ser un eje central que opera conjuntamente con las campañas publicitarias en curso. En efecto, en un mecanismo de retroalimentación, las campañas son usadas para llevar el tráfico de destinatarios al portal y viceversa de tal manera que irradie la imagen de un destino denso y diverso. Al formar parte de una estrategia global de exhibición del país, el portal conserva la esencia del mensaje de la campaña I need Spain, pero su discurso se adapta al género y se estructura mediante el hipertexto, en función de la pluralidad de objetivos y del destinatario. Turespaña aprovecha así las Tecnologías de la Información y la Comunicación (TIC) para llegar a un auditorio tan amplio como lo son los mercados internacionales.

Para ese público, en un estilo poco depurado, pero con material de peso, el locutor consigue generar un ethos de confianza que avala su trabajo discursivo de mostración de la ciudad. A su vez perfila a un viajero distinguido que adhiere a una imagen turística de Madrid cargada de historia y arte: el locutor moviliza el Madrid de los Austrias (siglos XVI-XVII), de los Borbones (siglos XVIII-XIX; principios del XX) así como los museos. Completa el pasado histórico y el legado artístico de la ciudad con la faceta moderna y cosmopolita y se ajusta a las normas turísticas existentes que consisten en exhibir los lugares de fuerte capital simbólico. El locutor hace uso de imágenes sugestivas y del poder creador de la palabra para nombrar la ciudad ante el destinatario. La idea es que para él Madrid acabe siendo lo que se dice de ella.

Esa retórica en la pantalla, lejos de disminuir el interés por el viaje, aumenta la necesidad de la experimentación física. Así, a través de las modalidades de prácticas de la ciudad, el destinatario se corporeiza en el texto y, de la mano del locutor, se mueve céntricamente en el espacio, como en ciertas guías de viaje. Con ello, Turespaña consigue crear expectativas sensoriales y generar la necesidad de evasión.

En los fragmentos discursivos, el locutor modula tanto el perfil de ambas instancias como su presencia y la relación al otro. A veces muy presente, otras en la penumbra, el locutor orquestra sus apariciones y busca crear vínculos hacia el destino, por supuesto, 
pero también en torno a él, vía la introducción de enlaces comunitarios virtuales. En esos espacios, el discurso se inscribe polifónicamente en torno a una práctica turística que consiste en la observación activa del entorno. La escritura a varias manos confirma y autentifica el mensaje de la campaña, pero creemos, también, que regenera la visión sobre el tipo de turismo que tiene lugar en España. Los recuerdos ponen en escena ejemplos y quizá modelos de prácticas turísticas más experimentales.

De la presente investigación se desprende la necesidad de ahondar en el análisis de la comunicación turística en el ámbito español, online y offline, ampliando el estudio de campo a las estrategias argumentativas empleadas en campañas de marketing integrado conocidas como marketing $360^{\circ}$. Se sugiere, asimismo, la elaboración de un planteamiento comparativo en investigaciones futuras mediante el cual se pueda analizar paralelamente el discurso turístico aplicado a la imagen de Madrid en Spain.info y en la promoción de la Marca España en el mundo.

\section{BIBLIOGRAFÍA}

ALT64 y AIMC (2005): Análisis del comportamiento visual de los internaturas y la efectividad de la publicidad online». Disponible en http://www.alt64.com/tobiiftp/ Eyetracking_Media_Espana.pdf. Consultado el 23 de mayo de 2012.

ALONSO, J. (2010): «Cibermedios: conceptualización y tipologías», en Evolución tecnológica y cibermedios. Zamora, Comunicación Social Ediciones y Publicaciones, pp. 21-38.

AMOSSY, R. (2006): L’Argumentation dans le discours. París, Armand Colin.

CALVI, M.V. (2006): Lengua y comunicación en el español del turismo. Madrid, Arco Libros.

CALVI, M.V. (2009): «Los géneros discursivos en la lengua del turismo: una propuesta de clasificación», en Ibérica. Revista de la Asociación Europea de Lenguas para Fines Específicos, $\mathrm{n}^{\circ} 19$, pp. 9-32. Disponible en http://www.aelfe.org/documents/01_19_ Calvi.pdf. Consultado el 19 de mayo de 2012.

CALVI, M.V. y MAPELLI, G. (2010): «La presencia de términos culturales en las páginas web de turismo», en Actas del XVI Congreso de la Asociación Internacional de Hispanistas: Nuevos caminos del hispanismo (París, 9-13 de julio de 2007), pp. 43-51.

COËFFÉ, V. y VIOLIER, P. (2008): «Les lieux du tourisme: de quel(s) paradis parle-ton? Variations sur le thème de l'urbanité touristique», en Journal of Urban Research. Disponible en http://teoros.revues.org/158. Consultado el 20 de junio de 2014.

CHIERICHETTI, L. (2010): «La persuasión en las páginas web de los organismos institucionales de turismo: el portal www.spain.info», en Actas del XVI Congreso internacional de Hispanistas: Nuevos caminos del hispanismo, vol. 2. (CD.ROM).

CUADRADO ROURA, J.R. y LÓPEZ MORALES, J.M. (2011): «El turismo: un sector clave en la economía española», Papeles de Economía Española, no 128, pp. 2-20.

FRONTUR-INSTITUTO DE ESTUDIOS TURÍSTICOS (2013): Movimiento Turísticos en Fronteras (Frontur) y Encuesta de Gasto Turístico (Egatur) 2012. Disponible en http://www.iet.tourspain.es. Consultado el 29 de julio de 2014.

FRONTUR- NSTITUTO DE ESTUDIOS TURÍSTICOS (2014): Nota de coyuntura de Frontur. Diciembre 2013. Disponible en http://www.iet.tourspain.es. Consultado el 5 de agosto de 2014. 
GONZÁLEZ GARCÍA, V. (2012): «El discurso del turismo en Internet», en Discurso turístico e Internet. Madrid, Iberoamericana, pp. 13-49.

HASSAN MONTERO, Y. y HERRERO SOLANA, V. (2007): «Eye-Tracking en Interacción Persona-Ordenador», No Solo Usabilidad, $\mathrm{n}^{\circ}$ 6. Disponible en http://nosolousabilidad. com/articulos/eye-tracking.htm. Consultado el 23 de mayo de 2012.

HULBERT, F. (2009): «L'espace politique de la ville: plaidoyer pour une géopolitique urbaine», e L'Espace Politique, $\mathrm{n}^{\circ}$ 8. Disponible en http://espacepolitique.revues. org/1330. Consultado el 19 de julio de 2012.

INTERNET WORLD STATS (2012): «World Internet Usage and Population Statistics, June 30». Disponible en http://www.internetworldstats.com/stats.htm. Consultado el 28 de abril de 2014.

LÓPEZ GARCÍA, X.; LIMIA FERNÁNDEZ, M.; ISASI VARELA,A.; PEREIRA FARIÑA, X.; GAGO MARIÑO, M. y CALVO DIÉGUEZ, R. (2005): «Tipología de los cibermedios», en Cibermedios. El impacto de Internet en los medios de comunicación en España. Sevilla, Comunicación Social, pp. 39-70.

MAINGUENEAU, D. (2009a): «Auteur et image d'auteur en analyse du discours», en Argumentation et Analyse du Discours, $\mathrm{n}^{\circ} 3$. Disponible en http://aad.revues.org/660. Consultado el 2 de julio de 2014.

MAINGUENEAU, D. (2009b): Aborder la linguistique. París, Éditions du Seuil.

MOIRAND, S. (2004): «Le même et l'autre», en La communication touristique. Approches discursives de l'identité et de l'altérité. París, L'Harmattan.

OLU, E. (2008): «L'argument culturel du "touristique", l'argument touristique du culturel, symptômes de "la fin du muséal"», Téoros, vol. 27, n 3. Disponible en http://teoros. revues.org/63. Consultado el 5 de junio de 2014.

PARRA VALCARCE, D. y ÁLVAREZ MARCOS, J. (2004): Ciberperiodismo. Madrid, Síntesis.

RODRÍGUEZ ABELLA, R. (2012): «La lengua de la promoción turística institucional. Análisis del portal www.spain.info», Pasos. Revista de Turismo y Patrimonio Cultural, vol. 10, $\mathrm{n}^{\mathrm{o}} 4$, pp. 115-126. Disponible en http://www.redalyc.org. Consultado el $21 \mathrm{de}$ febrero de 2015.

SHEPHERD, M. y WATTERS, C. (1998): «The evolution of Cybergenres». Disponible en http://web.cs.dal.ca/ shepherd/pubs/evolution.pdf. Consultado el 19 de julio de 2012.

TANGUAY, J. (2004): «La qualité en tourisme: de la norme à la déstandardisation», Téoros, vol. 23, $n^{o}$ 2. Disponible en http://teoros.revues.org/628. Consultado el 4 de Junio 2014.

THE GLOBE SHOPPER INDEX (2012): Globe Shopper Index rankings. Disponible en http://globeshopperindex.com/en/Methodology. Consultado el 10 de febrero de 2015

TURESPAÑA (2015): Marketing on line. Disponible en http://www.tourspain.es/. Consultado el 7 de febrero de 2015.

UNITED NATIONS WORLD TOURISM ORGANIZATION (UNWTO). Panorama del Turismo Internacional. (2014). Disponible en http://www2.unwto.org/. Consultado el 15 de julio de 2014.

VERGOPOULOS, H. y FLON, E. (2012): «L'expérience touristique dans les guides: une subjectivité à lire, écrire et raconter», Belgeo, $\mathrm{n}^{\circ} 3$. Disponible en http://belgeo.revues. org/7173. Consultado el 11 de junio 2014. 
